\title{
THE UNITED STATES AND INTERNATIONAL CRIMINAL TRIBUNALS: AN HISTORICAL ANALYSIS
}

\author{
Harry M. Rhea
}

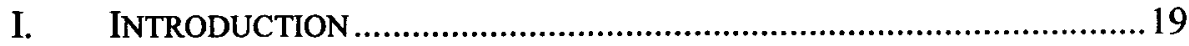

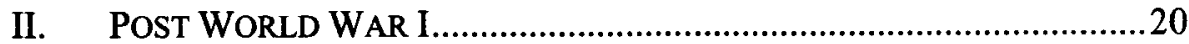

III. POST WORLD WAR II: NUREMBERG AND TOKYO ...........................21

IV. CONVENTION ON THE PREVENTION AND PUNISHMENT OF THE CRIME

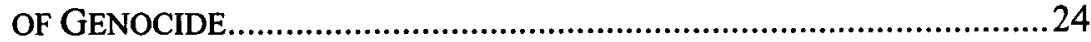

V. AN INTERNATIONAL CRIMINAL TRIBUNAL FOR IRAQ........................28

VI. THE INTERNATIONAL CRIMINAL TRIBUNAL FOR THE FORMER

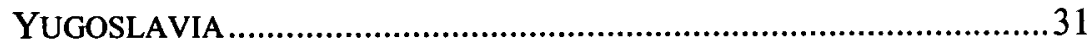

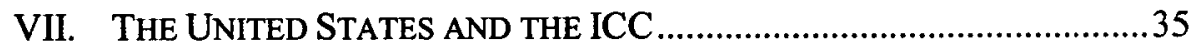

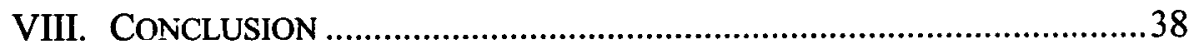

\section{INTRODUCTION}

The relationship between the United States and international criminal tribunals has lasted for almost 100 years at least. At first glance, a chronology of the relationship would lead one to think that the United States policy has been extremely inconsistent. This would be displayed only after comparing the United States' dissent against an international criminal tribunal after World War I (WWI), to the United States' support of the International Military Tribunal (IMT) after World War II (WWII), and its support of an International Criminal Court (ICC) at the Genocide Convention.

Beginning in the early 1990 's, the United States did not support a Security Council (SC) international tribunal for Iraq, but later changed its position as well as supported SC international tribunals for the former Yugoslavia and Rwanda. In 1993, the United States supported the creation of the permanent ICC, but later voted against it in 1998. Considering these inconsistencies, it would seem that the United States does not have a consistent policy regarding international criminal tribunals.

Taking a closer look at the chronology, a consistent position would become clearer: the United States has not favored international criminal tribunals when there is substantial risk of United States nationals being

* The author is Assistant Professor of Criminal Justice at the Richard Stockton College of New Jersey, USA, and Ph.D. Candidate at the Irish Centre for Human Rights, National University of Ireland, Galway. 
indicted. The purpose of this section is to display, chronologically, how the United States has remained consistent with this position from post WWI to the present.

\section{POST WORLD WAR I}

After WWI the United States dissented against the creation of an international criminal tribunal to prosecute German war criminals, particularly the former Kaiser of Germany, Wilhelm II of Hohenzollern, for his participation in acts of aggression which instigated the war. ${ }^{1}$ The United States, however, did not argue against national prosecutions by any occupying Allied power or the state of the nationality of the accused and even favored a tribunal with "international character" if "formed by the union of existing national military tribunals or commissions." tribunal would not have been an "international" tribunal per se, but a multinational tribunal. Moreover, the United States stated in its dissent that "legal offenses were justiciable and liable to trial and punishment by appropriate tribunals." "Appropriate tribunals" would have been national courts, state or military, by either the state that the accused was a national citizen, or the state of an opposing army, or a tribunal combining national jurisdiction voluntarily creating a multinational military tribunal.

The United States also argued strongly against the attempt to prosecute persons high in authority for acts committed by their subordinates. In its dissent, the United States stated that in the case of indirect responsibility for violations of the laws and customs of war committed after the outbreak of the war, there was an attempt to "punish certain persons, high in authority, particularly the heads of enemy states, even though heads of States were not hitherto legally responsible for the atrocious acts committed by subordinate authorities."4 This "indirect responsibility" was an issue that the United States would not compromise. ${ }^{5}$

For which reasons exactly the United States was so against indirect responsibility are not clear. As the following pages will indicate, it is more likely the United States did not favor the thought of its own nationals in higher authority ever being indicted by an international tribunal. Without

1. Commission on the Responsibility of the Authors of the War and on Enforcement of Penalties: Report Presented to the Preliminary Peace Conference American Journal of International Law, 14 AM. J. INT'L L. 95, 127-151 (1920), reprinted in 1 AM. J. INT'L L. 95, 154 (1920) [hereinafter Commission].

2. Id. at 129 .

3. Id. at 128.

4. Id.

5. Id. 
precedent or support for the court, the possibility of a United States national in higher authority ever being prosecuted in an international court was diminished. In its dissent of an international criminal tribunal and the prosecutions of persons in higher authority, the United States was not concerned with the past but the future.

\section{POST WORLD WAR II: NUREMBERG AND TOKYO}

From 19 October through 30 October 1943, the United States, United Kingdom, and the Soviet Union met in Moscow and signed the Moscow Declaration, ${ }^{6}$ which was the first jointly signed proclamation that the Allied powers would prosecute the hierarchy of German war criminals when the war ended. ${ }^{7}$ On 24 March 1944, Franklin Roosevelt declared that:

[i]t is therefore fitting that we should again proclaim our determination that none who participate in these acts of savagery shall go unpunished. The United Nations have made it clear that they will pursue the guilty and deliver them up in order that Justice be done. That warning applies not only to the leaders but also to their functionaries and subordinates in Germany and in the satellite countries. All who knowingly take part in the deportation of Jews to their death in Poland, or Norwegians and French to their death in Germany are equally guilty with the executioner. All who share the guilt shall share the punishment. ${ }^{8}$

The words of President Roosevelt are quite clear that the United States had changed its policy from post WWI when it dissented against prosecuting those indirectly responsible for crimes. Not only was the executioner responsible, but also all participants, including persons of higher authority, were "equally guilty with the executioner." However, the Allied victors would be careful to create a tribunal particularly for the prosecution of certain persons in higher authority that they would agree.

WWII ended in Europe on 8 May 1945, but prosecution plans were already underway. On 12 April 1945, President Roosevelt died, but his successor, President Harry S. Truman, made no doubt that he wanted an

6. Declaration of German Atrocities, 9 DEP'T ST. BULL. Nov. 16, 1943, Vol. DX, at 310-11.

7. WHITNEY R. HARRIS, TYRANNY ON TRIAL: THE TRIAL OF THE MAJOR GERMAN WAR CRIMINALS AT THE END OF World War II AT NuREMBERg Germany 56 (Southem Methodist University Press, 1999) (1954); see also, ARIEH J. KochavI, Prelude to NuREMBERG: Allied WAR CRIMES POLICY AND THE QUESTION OF PUNISHMENT S6-57 (1998).

8. ROBERT H. JACKSON, UNITED STATES REPRESENTATIVE TO THE INTERNATIONAL CONFERENCE ON MILITARY TRIALS 12-13 (1945) [hereinafter Jackson]. 
international military tribunal to prosecute the major Nazi war criminals. ${ }^{9}$ On 2 May 1945, President Truman officially designated Associate United States Supreme Court Justice, Robert H. Jackson, to represent the United States at the London Conference to lead the way in developing the London Charter, and prosecuting Nazi war criminals on behalf of the United States. $^{10}$

On 26 June 1945, when the Allied victors met at the International Conference on Military Trials [hereinafter London Conference] it was obvious from the start that there would be friction between the Allied victors in establishing not only the rules, but the goals of the IMT. The Soviet Union insisted that all defendants be found guilty in the end. ${ }^{11}$ Justice Jackson argued that "if we are going to have a trial, then it must be an actual trial." ${ }^{\prime 2}$ He contemplated that the United States should prosecute alone saying that "the idea of separate trials for each nation for the trial of its separate groups of prisoners may be the easiest and most satisfactory way of reconciling it." 13 In early June, Justice Jackson made clear in his report to the President that the United States case would preferably be conducted in "association with others, but alone if necessary." States had in its custody many German war criminals ${ }^{15}$ and was capable of successfully prosecuting them. Eventually, Justice Jackson would win the argument and the Soviet Union agreed that the IMT would not be a show trial with pre-decided verdicts.

The United States insisted that it was important to prosecute together and establish a precedent that certain crimes would not be tolerated by the international society. The United States remained consistent with its dissent for creating an international criminal tribunal after WWI. The IMT was a multinational military tribunal with "international character" and "formed by the union of existing national military tribunals or commissions," which is the type of court that the United States favored after WWI.

The United States did, however, change its policy regarding prosecuting persons with higher authority who were indirectly responsible

9. Telford Taylor, The ANatomy of the NUREMburg TRIALS 32 (1992) [hereinafter Taylor].

10. 10 C.F.R. 4691 , Exec. Order No. 9547.

11. Jackson, supra note 8, at 104-05.

12. Id. at 115 .

13. Id.

14. ROBERT H. JACKSON, Atrocities and War Crimes, 12 DeP'T ST. BULL. 1071, 1073 (1945) [hereinafter Robert].

15. Id.

16. Commission, supra note 1 , at 129. 
for the atrocities committed by subordinates during the war. Justice Jackson's aim was to prosecute the top Nazi officials, also known as the "ringleaders", who were responsible for planning and ordering crimes. Even though they may not have pulled the trigger or turned on the gas, superiors were most responsible for the crimes committed if they were planned or ordered. In his Report to the President, Justice Jackson validated his position referring to United States national criminal justice system by stating that: by not prosecuting higher authorities, it would be "inconsistent with the position we take toward our own officials, who are frequently brought to court at the suit of citizens who allege their rights to have been invaded."17

Changing its policy on the prosecution of superiors indirectly responsible for crimes committed by subordinates, the United States foresaw that it, too, as well as other Allies could be called into the dock. To prevent any of their own nationals from being prosecuted, Justice Jackson and other Allied representatives at the London Conference agreed that their own nationals would not be within the jurisdiction of the IMT; the first sentence of Article 3 of the London Charter stated, "[n]either the Tribunal, its members nor their alternates can be challenged by the prosecution, or by the Defendants or their Counsel.".18

The International Military Tribunal of the Far East (IMTFE) was established to prosecute Japanese war criminals that committed atrocities during WWII. Similar to the IMT, the jurisdiction of the IMTFE did not cover any of the Allied nationals. Instead of a Tokyo conference, the Charter of the IMTFE was an executive decree of General MacArthur on 19 January 1946. ${ }^{19}$ As a result, the United States had more control over it and established in Article 5 that " $[\mathrm{t}] \mathrm{he}$ Tribunal shall have the power to try and punish Far Eastern war criminals who as individuals or as members of organizations are charged with offences which include Crimes against Peace., 20

It is clear that the United States took the position that, consistent with national courts the prosecutors of the multinational military tribunals had the power to decide which defendants to prosecute. Therefore, even if it is argued that it was possible for United States nationals to be prosecuted for crimes within the jurisdiction of the tribunals, the United States prevented this through its prosecutorial discretion. Justice Jackson, in his attempt to

17. Robert, supra note 14.

18. U.N. Doc. A/CN.4/5 (1949), art. 3.

19. Solis Horwitz, The Tokyo Trial, in No. 465, INTERNATIONAL CONCILIATION, 471, 480 (Anne Winslow ed., Carnegie Endowment)(1950).

20. Charter of the International Military Tribunal for the Far East, art. 5, Jan. 19, 1946. 
legitimize prosecuting persons of higher authority, claimed that United States officials are also brought to court for violating rights of others. ${ }^{21}$ This was not true to the standard of international law. Never had a United States official in a position of higher authority been prosecuted in a national court for international crimes. One could argue the Trial of Henry Wirz after the American Civil War, ${ }^{22}$ but Wirz was not an officer in the United States Army; he was an officer in the Confederate Army. Further, the United States did not prosecute military or political officials of higher authority for crimes committed during WWII. Therefore, the United States may have changed its policy since post WWI when it argued against indirect criminal responsibility, but only for ad hoc courts, national or multinational, when it had prosecutorial discretion.

\section{CONVENTION ON THE PREVENTION AND PUNISHMENT OF THE CRIME OF GENOCIDE}

In 1946, while the IMT at Nuremberg had completed and the IMTFE was still in session, there begun discussion concerning the creation of a permanent ICC or a court with international criminal jurisdiction. With the exception of much criticism, the IMT was considered a success, overall. As a result, the General Assembly [hereinafter GA], instructed the International Law Commission [hereinafter ILC], to establish basic principles of international law from the IMT. ${ }^{23}$ The GA adopted the Principles of International Law Recognized in the Charter of the Nuremberg Tribunal and in the Judgment of the Tribunal in $1950 .{ }^{24}$

The GA also developed a committee to consider the creation of a permanent ICC and to draft a statute for the court. ${ }^{25}$ The committee reported to the GA in 1952 and stated that a permanent ICC was feasible. ${ }^{26}$ Unfortunately, with the lack of a definition for the crime of aggression and the height of the Cold War, the project was suspended indefinitely. ${ }^{27}$

21. Robert, supra note 14.

22. Proceedings of a Special Military Commission Convened at Washington D.C. in pursuance of the following Special Orders No. 453, 23 August 1865, National Archives, Washington D. C., RG 153, Records of the Office of the Judge Advocate General (Army), Court Martial Case Files 1809-1894, MM2975, Box 1264, Folder \#1 mm 2975.

23. G.A. Res. 177(II)(a)(1947), U.N. Doc. A/519 (1947).

24. U.N.Y.B. Int'l L. Comm'n 374, U.N. Doc. A/1316 (1950).

25. G.A. Res. 174(III)(a), U.N. Doc. AV519 (1947).

26. Report of the Committee on Int'l Criminal Jurisdiction A/2136, reprinted in 2 BENJAMIN B. Ferencz, an International Criminal Court: a Step toward World Peace-A DOCUMENTARY HISTORY AND ANAL YSIS 337 (1980) [hereinafter Ferencz].

27. G.A. Res. 897 (IX) (1954). 
Preceding the instructions to the ILC by the GA to consider the creation of a permanent ICC, there was much debate during the drafting of the Convention on the Prevention and Punishment of the Crime of Genocide, ${ }^{28}$ adopted in 1948. Originally, Article VI of the Genocide Convention legally obligated states to an ICC if genocide, ${ }^{29}$ or other acts of genocide, ${ }^{30}$ were committed. This legal obligation of states to an ICC was controversial and many states, including the Soviet "bloc," argued such a court violated state sovereignty and states were only obligated to courts already established under national jurisdiction. The United States representatives, however, favored adopting a convention that included establishing an ICC. ${ }^{31}$

Prior to the Genocide Convention, a draft convention was prepared by the United Nations (UN) Secretariat. The Secretariat's draft referred to the ICC in Article IX as obligatory for state parties to the Convention under two conditions. Article IX read as follows:

The High contracting Parties pledge themselves to commit all persons guilty of genocide under this Convention for trial to an international court in the following cases: When they are unwilling to try such offenders themselves under Article VII or to grant their extradition under Article VIII. If the acts of genocide have been committed by individuals acting as organs of the State or with the support of toleration of the state. ${ }^{32}$

The following article described the ICC either "having jurisdiction in all matters connected with international crimes"33 or jurisdiction over the crime of genocide, only.

On 3 March 1948, the Economic and Social Council [hereinafter ECOSOC] created the Ad Hoc Committee on Genocide to develop a draft convention. The United States representative, Mr. John Maktos, chaired the

28. Convention on the Prevention and Punishment of the Crime of Genocide, February 12, 1951, 78 U.N.T.S. 277.

29. Id. at $280-282$.

30. Id.

31. Lawrence J. Leblanc, The Untted States and the Genocide Convention 151 (1991) [hereinafter LeBlanc].

32. U.N. Econ. \& Soc. Council [ECOSOC], Draft Convention on the Crime of Genocide, U.N. Doc. E/447, 8 (June 26, 1947) [hereinafter Crime of Genocide].

33. Id. 
Ad Hoc Committee. ${ }^{34}$ It held meetings from 5 April through 10 May 1948 and published its report on 24 May 1948. ${ }^{35}$ Although the Ad Hoc Committee previously decided to use the Secretariat's draft convention as a basis, which stipulated that "[t]he High contracting Parties pledge themselves to commit all persons guilty of genocide under this Convention for trial to an international court, ${ }^{, 36}$ it later decided only to take it into consideration. ${ }^{37}$ The Ad Hoc Committee would drastically revise the Secretariat drafts' provisions regarding an ICC. ${ }^{38}$

During the discussions, there was more agreement on the principle of an international criminal jurisdiction rather than an ICC. ${ }^{39}$ John Maktos proposed the creation of an ICC that would have a complementary role to national courts. His proposal stated: "Assumption of jurisdiction by the international tribunal shall be subject to a finding by the tribunal that the state in which the crime was committed has failed to take adequate measures to punish the crime." 40

The United States proposal was defeated in a vote of 5-1 and was not included in the draft convention. ${ }^{41}$ The mention of an ICC in the Draft Convention was subtle. Article VII reads as follows: "Persons charged with genocide or any of the other acts enumerated in Article IV shall be tried by a competent tribunal of the state in the territory of which the act was committed or by a competent international tribunal., 42

The majority of states were not ready for an ICC and agreed that more research had to be completed. To prevent the Genocide Convention from not being adopted, the United States proposed that the problem of the ICC be dealt with in a separate Convention to be drafted by the $\mathrm{IC}^{43}$ and the court, if created, would have jurisdiction over states that accepted jurisdiction through ratification. The GA adopted the Genocide Convention on 9 December 1948. Article VI stated that persons accused of genocide would be prosecuted by the state on which territory the crime was

34. U.N. Econ. \& Soc. Council [ECOSOC], Ad Hoc Committee on Genocide, Report of the Committee and Draft Convention Drawn up by the Committee, U.N. Doc. E/794, 1 (April 5-May 10, 1948) [hereinafter Ad Hoc].

35. Id.

36. Crime of Genocide, supra note 32.

37. Ad Hoc, supra note 34, at 4.

38. Ferencz, supra note 26, at 12.

39. Ad Hoc, supra note 34 , at 30.

40. Id.

41. Id.

42. Id. at 56 .

43. Ferencz, supra note 26 , at 10. 
committed or "by such international penal tribunal as may have jurisdiction with respect to those Contracting Parties which shall have accepted its jurisdiction." ${ }^{44}$

The completion of the Genocide Convention was not the completion of internal debates within the United States concerning Article VI. ${ }^{45}$ There was much urging to ratify the Genocide Convention for two reasons: (1) ratifying the Convention would not contract the United States to the jurisdiction of a future ICC. There was no court at the time and if one came to effect, the United States did not have to accept its jurisdiction; ${ }^{46}(2)$ Genocide had never existed, nor could it ever exist in the United States guaranteed by the United States Constitution and Bill of Rights. ${ }^{47}$

During the 1950s Senate Hearings, opponents of Article VI feared the Genocide Convention and any future ICC could be used politically against the United States, including national racial segregation. Even though segregation did not include the special intent dolus specialis to destroy the group, in whole or in part, required under Article $\mathrm{II},{ }^{48}$ there was certainly fear that the argument could be made.

The fear of politically motivated accusations of genocide by the United States was soon justified. On 17 December 1951, the Civil Rights Congress submitted a petition to the UN titled "We Charge Genocide: The Crime of Government Against the Negro People." ${ }^{49}$ The allegation stated "that within an unspecified number of years 10,000 negroes were killed and that the US Government intends the destruction of 15 million negroes." Earlier in the year, the United States learned that the Soviet Union was aware of the accusation and stated, "[i]t is to be expected that the accusation of genocide vs. the American Negro will be publicized by all means within the United Nations General Assembly (UNGA), regardless whether the charge is formally accepted on the GA agenda." ${ }^{51}$

44. Convention on the Prevention and Punishment of the Crime of Genocide, art. VI, Jan. 12, 1951, 78 U.N.T.S. 277.

45. See generally The Genocide Convention: Hearing Before the S. Comm. on Foreign Relations, 81 st Cong. (1950).

46. Id. at 44 .

47. Id. at 53 .

48. Convention on the Prevention and Punishment of the Crime of Genocide, supra note 44, at art. II.

49. See generally We Charge Genocide: The Crime of Government Aganst the NEGRo PEOPLE (William L. Patterson ed,. 1970).

50. Letter from I.B.D. N.Y. Kohler to John Devine, Possible Lines of Approach to Meet the Communist Charge of Attempted Genocide Against the Negros of the U.S.A. by the U.S. Government (Mar. 17, 1951) (on file with author).

51. Id. at 1 . 
Though nothing significant developed from the petition against the United States for the crime of genocide against American Negroes, this was an example that countries against each other could use charges of international crimes politically. States at the Genocide Convention, particularly the Soviet "bloc" understood that some of their national laws of oppression could arguably be considered international crimes, if not genocide. The United States did not ratify the Genocide Convention for nearly forty years after its adoption by the GA. On 23 November 1988 the United States submitted its ratification of the Genocide Convention. However, an earlier resolution was passed concerning the ratification. ${ }^{52}$ In the resolution, the United States confirmed that its nationals would not be within the jurisdiction of any future ICC by stating:

That with regard to the reference to an international penal tribunal in Article VI of the Convention, the United States declares that it reserves the right to effect its participation in any such tribunal only by a treaty entered into specifically for that purpose with the advice and consent of the Senate. ${ }^{53}$

The debates within the United States Senate from 1950 until ratification of the Convention in 1988 remained consistent regarding an ICC in Article VI. Opponents openly wished not to have any possible connection to such a court. Proponents agreed that an ICC should not have jurisdiction over United States nationals unless contracted by a separate treaty. In either case, there was no strong support for an ICC that would have jurisdiction over United States nationals.

\section{AN INTERNATIONAL CRIMINAL TRIBUNAL FOR IRAQ}

On 2 August 1990, Iraq invaded Kuwait beginning the First Gulf War. The following day, the Office of the Judge Advocate General (JAG) of the United States Army began to informally collect evidence that United States citizens were taken hostage in Kuwait by Iraqi military personnel and forcibly deported to Iraq. ${ }^{54}$ In December 1990 , United States hostages were released and, on 24 December 1990, the United States formally opened an

52. LeBlanc, supra note 31 , at 253.

53. Id. at 253-54.

54. Memorandum from John H. McNeill, Deputy General Counsel, Int'l Affairs \& Intelligence, to Judge Advocate Gen., Dep't of the Army (Nov. 19, 1992) (on file with author) [hereinafter McNeill]. 
investigation into violations of international humanitarian law by the Iraqi military. ${ }^{55}$

It was hoped that the evidence obtained would be used in future prosecutions of Iraqi military personnel who committed war crimes. ${ }^{56}$ President George H. W. Bush publicly hinted at prosecuting Saddam Hussein in October 1990, when he called the Iraqi president "Hitler Revisited." 57 He subsequently referred to the Nuremberg Trials, which prosecuted Nazi war criminals after WWII. ${ }^{58}$

President George H. W. Bush's administration was unsure how to pursue a war crimes tribunal. With the exception of the IMT and the IMTFE, no such international criminal tribunal had ever existed. The United States did not favor prosecuting Iraqi war criminals unilaterally as this would reflect "victors' justice"; but the United States also did not favor including the United Nations in the process. ${ }^{59} \mathrm{M}$. Cherif Bassiouni, writes that he was contacted by a partner of a Saudi law firm in Riyadh to solicit his views on a proposal for an Arab League initiative to establish an Arab war crimes tribunal for Iraq. ${ }^{60}$ The idea of the proposal was assumed to have originated from a United States government source. ${ }^{61}$ The Arab League did not pursue a war crimes tribunal for Iraq as a result of uninterested Arab governments. ${ }^{62}$

55. Id. at 4-5.

56. Id. at 8; see also Bob Cohn \& Ginny Carroll, To the Victors Go the Trials, NEWswEEK, Feb. 4, 1991, at 52; Tony Mauro, War-Crimes File Against Saddam is Building, USA ToDAY, Feb. 13, 1991, at A4.

57. Secretary Baker, Iragi Atrocities in Kuwait, 1 U.S. DEP'T. OF STATE DISPATCH, 199, 205 (1990); Cohn \& Carroll, supra note 60; Gerald F. Seib, Bush Hints US to Seek War-Crime Trial of Iraq's Leaders for Actions in Kuwail, WALL ST. J., Oct. 16, 1990, at A8; Neal Ascherson, The Trial of Saddam Hussein: Retribution Belongs to His Victims in Iraq, INDPT. (London), Oct. 21, 1990, at 19; Peter Kellner, Why Iraq War Crimes May go Unpunished, INDPT. (London), Feb. 1, 1991, at19 [hereinafter Kellner]; see also Louis René Beres, Toward Prosecution of Iraqi Crimes Under International Law; Jurisprudential Foundations and Jurisdictional Choices, 22 CAL. W. INT'L L.J. 127, 127-34 (1991); Louis René Beres, Prosecuting Iragi Crimes: Fulfilling the Expectations of International Law After the Gulf War, 10 DICK. J. INT'L L 425, 426, 427 (1992); Louis René Beres, Iraqi Crimes and International Law: The Imperative to Punish, 21 DENV. J. INT'L L. \& POL'Y 335, 345-48 (1993); Louis René Beres, Iraqi Crimes During and Afier the Gulf War: The Imperative Response of International Law, 15 LOY. L.A. INT'L \& COMP. L.J. 675, 675-89 (1993).

58. Seib, supra note 57; Ascherson, supra note 57.

59. M. Cherif Bassiouni, Events Leading to the Creation of the IHT, reprinted in MICHAEL P. SCHARF \& GREgORY S. MCNEAL, SADDAM ON TRIAL: UNDERSTANDING AND DEBATING THE IRAQI High TRIBUNAL 11 (2006).

60. Id. at $11 \& 395$ n.34.

61. Id. at 11 .

62. Id. 
For the following decade, the United States would continue to struggle over methods to bring Saddam Hussein to justice. After the SC established the International Criminal Tribunals for the former Yugoslavia and Rwanda, the United States Senate passed Senate Resolution 78 in March 1998 , urging the creation of a United Nations international criminal tribunal to prosecute Saddam Hussein and other Iraqi officials for war crimes. ${ }^{63}$ The Senate resolution stated that the President of the United States should:

1) call for the creation of a commission under the auspices of the United Nations to establish an international record of the criminal culpability of Saddam Hussein and other Iraqi officials;

2) call for the United Nations to form an international criminal tribunal for the purpose of indicting, prosecuting, and imprisoning Saddam Hussein and any other Iraqi officials who may be found responsible for crimes against humanity, genocide, and other violations of international humanitarian law; and

3) upon the creation of a commission and international criminal tribunal, take steps necessary, including the reprogramming of funds, to ensure United States support for efforts to bring Saddam Hussein and other Iraqi officials to justice. ${ }^{64}$

The Senate hoped that President Clinton would take a more proactive approach to bring Saddam Hussein to trial by persuading the SC to establish an international criminal tribunal for Iraq just as it did for the former Yugoslavia and Rwanda. ${ }^{65}$ In 1999, the United States pursued criminal charges against Saddam Hussein and company. ${ }^{66}$ David Scheffer, the United States Ambassador for War Crimes, stated that the goal of the United States was to bring Saddam Hussein to justice. ${ }^{67}$ Ultimately, Russia and China did not support the creation of an ad hoc international criminal tribunal for Iraq and opposed any such tribunal. ${ }^{68}$

63. S. Con. Res. 78, 105th Cong. (1998); see also Mary Ann Akers, Senate Calls for UN Trial of War Criminal Saddam, WASH. TIMES, Mar. 14, 1998, at A03; Helen Dewar, Senate Urges Tribunal to Try Saddam: Iraqi is Targeted as War Criminal, WASH. PoST, Mar. 14, 1998, at A20.

64. S. Con. Res. 78.

65. Walter Pincus, Senators Urge Undermining of Saddam: Republicans Propose \$38 Million for Foes of Iraqi Leader, WASH. POST, Mar. 11, 1998, at A6.

66. Warren P. Strobel \& Kevin Whitelaw, Saddam Hussein and the Bar of Justice: Can Lawyers Succeed where Bombs Failed?, U.S. NEWS \& WORLD REP., Oct. 25, 1999, at 40.

67. Id.

68. Id. 


\section{THE INTERNATIONAL CRIMINAL TRIBUNAL FOR THE FORMER YUGOSLAVIA}

On 12 December 1992, the United States formally took the position that it was in favor of an ad hoc international criminal tribunal. United States Secretary of State, Lawrence Eagleburger, "publicly called for the creation of a Nuremberg-like tribunal to try persons believed to be responsible for atrocities in the former Yugoslavia,"69 and accused Slobodan Milosevic, Radovan Karadzic, and Ratko Mladic of committing international crimes during the ethnic cleansing. Again, the United States promoted an ad hoc international criminal tribunal similar to Nuremberg just as it had with Iraq two years earlier.

President George H. W. Bush was reluctant to call for an international criminal tribunal for the former Yugoslavia (ICTY). Until the end of his presidential term, discussions continued about how to bring Saddam Hussein to trial and he had made known that he did not want to have a UN ad hoc tribunal for Iraq. ${ }^{70}$ Finally, with forty days left of President George H. W. Bush's presidency, his Secretary of State, Lawrence Eagleburger, called for an ad hoc tribunal. ${ }^{71}$ When the Clinton administration entered the White House, "Ambassador [Madeline] Albright's first initiative at the SC . . in February of 1993 was to create a war crimes tribunal for the Balkans. So as far as the Clinton Administration is concerned, we did it as issue number one." $" 72$

Chapter VII of the United Nations Charter is titled "Action with Respect to Threats to the Peace, Breaches of the Peace, and Acts of Aggression," "73 which authorizes the SC to take necessary actions "to maintain international peace and security." ${ }^{.74}$ There is no specific reference of the power to develop tribunals; however, there is the inherent right of

69. Elaine Sciolino, U.S. Names Figures to be Prosecuted Over War Crimes, N.Y. TIMES INT'L, Dec. 17, 1992, at A1[hereinafter Sciolino]; see also MICHAEL P. SCHARF, BALKAN JUSTICE: THE STORY BEHIND THE FIRST INTERNATIONAL WAR CRIMES TRIAL SINCE NUREMBERg 51 (1997); 1 VIRGINIA MORRIS \& MICHAEL P. SCHARF, AN INSIDER'S GUIDE TO THE INTERNATIONAL CRIMNAL TRIBUNAL FOR THE Former Yugoslavia 29 (1995); WILliam A. SCHABAS, THE UN INTERNATIONAL CRIMINal TRIBUnals: THE former Yugoslavia, RWANDa AND SiERRA LeONE 19 (2006).

70. Cherif Bassiouni, supra note 59, at 11.

71. Sciolino, supra note 69 , at A1; see also Scharf, supra note $69 ; 1$ Morris \& Scharf, supra note 69; Schabas, supra note 69.

72. Interview with David Scheffer, former US Ambassador for War Crimes Issues, Ir. (June $24,2008)$ [hereinafter Scheffer].

73. U.N. Charter ch. VII.

74. Theodor Meron, War Crimes in Yugoslavia and the Development of International Law, 88 AM. J. INT'L L. 78, 79 (1994). 
individual or collective self-defense. ${ }^{75}$ Therefore, there is consensus that if the $\mathrm{SC}$ has the authority to use force, which should be a last option, it also has the authority to create a judicial institution.

While the United States was consulting with its allies at the United Nations Commission on Human Rights in February 1993, France was circulating a draft SC resolution in New York, which would create a Yugoslavia war crimes tribunal. ${ }^{76}$ The United States immediately began working on a response to the French Draft, which requested the SC to approve and establish a Yugoslavia war crimes tribunal and subsequently approve the tribunal's statute. ${ }^{77}$ On 22 February 1993, the SC adopted Resolution 808 establishing an international criminal tribunal "for the prosecution of persons responsible for serious violations of international humanitarian law committed in the territory of the former Yugoslavia since 1991." 78

Seventeen states other than the United States submitted draft statute proposals to the UN Secretary General for consideration. ${ }^{79}$ On 8 May 1993, the SC adopted the tribunal's statute, officially activating the ICTY to bring to justice "persons responsible for serious violations of international humanitarian law committed in the territory of the former Yugoslavia since 1991."80

Eventually Justice Richard Goldstone was appointed Chief Prosecutor of the ICTY. Soon after, he was invited to the UN in New York for a briefing. ${ }^{81}$ He received great support from the United States when he arrived in New York. He stated:

I was warmly welcomed by Madeleine Albright, who had played the leading role in having the tribunal established. Her continued support for the work of the Yugoslavia tribunal, and later the Rwanda tribunal, was crucial to their success. She appointed one of her senior advisors, David Scheffer, to take special responsibility for moving the work of the tribunal forward. David became a friend and adviser to me, especially with regard to my contacts with the various branches of the

75. U.N. Charter art. 51.

76. Scharf, supra note 69 , at 52 .

77. Id. at 53.

78. S.C. Res. 808, $\Uparrow 1$, U.N. Doc. S/RES/808 (Feb. 22, 1993).

79. Scharf, supra note 69 , at 55.

80. Res. 827, I 2, U.N. Doc. S/RES/827 (May 25, 1993).

81. RICHARD J. GOLDSTONE, FOR HUMANITY: REFLECTIONS OF A WAR CRIMES INVESTIGATOR 76 (Yale University Press 2000). 
United States administration. His commitment to the work of both tribunals was deep and supportive. ${ }^{82}$

The ICTY would have failed in the early years if not for the contribution by the United States. Justice Goldstone stated that when he arrived at The Hague Convention there were forty staff members, twentythree were from the United States. When he left his post as prosecutor, there were 240 staff members and still twenthy-three were from the United States. ${ }^{83}$ The United States probably would have given more funds and personnel initially, but the UN would not allow this to prevent any view that the ICTY was a United States-controlled tribunal. ${ }^{84}$

United States Secretary of State, Madeleine Albright, was the driving force behind United States' support for the ICTY. She once lived in the Balkans and felt a connection to the territory. Justice Goldstone praised her helpfulness and the overall contribution of the United States. He stated that the United States gave him "whatever I wanted," and that "it was extraordinary to be able to reach an agreement with the United States to get intelligence information," and that no one would have thought the United States would have shared intelligence with an international prosecutor from South Africa. But the United States did share its intelligence and it was very helpful. Without the United States' political and economic muscle, there wouldn't have been a Yugoslavia tribunal. There was a genuine certainty on the part of the United States to have a working, successful international criminal tribunal. ${ }^{85}$

David Scheffer also believed that the United States was the only state that did its fair share of initially contributing to the ICTY. "In those very, very early months and first couple of years of the Yugoslavia Tribunal, we were not really getting the other governments to step forward and pitch in their fair share in support of the Yugoslavia Tribunal." ${ }^{86}$ He further stated, "[ $t]$ he United States was sort of the vanguard of pressing other governments to focus and support the Yugoslav Tribunal.."87

The compliments by Justice Goldstone describing the United States' support for the ICTY resembled its support for the IMT after WWII. Another resemblance is that when creating the statutes for both tribunals,

82. Id. at 78 .

83. Interview with Richard J. Goldstone, former prosecutor for the International Criminal Tribunals for the Former Yugoslavia and Rwanda, Georgetown Law School, (Mar. 19, 2008).

84. Id.

85. Id.

86. Scheffer, supra note 72.

87. Id. 
the United States had no intention of a United States national being prosecuted. Yet, a mistake was made with the ICTY statute and indictments of United States nationals were discussed.

The ICTY was created "for the Prosecution of Persons Responsible for Serious Violations of International Humanitarian Law Committed in the Territory of the Former Yugoslavia since 1991.,"88 This would include UN personnel and members conducting North Atlantic Treaty Organization (NATO) missions. In 1999, NATO dropped bombs on Kosovo attempting to end ethnic cleansing against the Albanians by the Serbs. The Bombings were conducted from excessively high altitudes and a high number of innocent civilians were killed. As a result, several nongovernment organizations (NGO) and legal scholars called for the indictment of NATO personnel, including United States officials of higher authority. ${ }^{89}$ The prosecutor of the ICTY at the time, Louise Arbour, and her replacement, Carla Del Ponte, "both insisted that the leaders of NATO, the United States, and any other parties involved in the Balkan wars were fair game for prosecution-if grounds were found." 90

While the media was publicizing the NATO airstrikes and the calls for the indictments of United States officials, on 22 May 1999, ICTY Prosecutor Louise Arbour presented an indictment for confirmation against Slobodan Milosevic. ${ }^{91}$ On 24 May 1999, Slobodan Milosevic was officially indicted for crimes against humanity and violations of international humanitarian law committed in Kosovo from 1 January 1999 to 20 June 1999. ${ }^{92}$ The NATO bombings had stopped in early June and Milosevic would later use the bombings in his defense stating that they were responsible for the mass killings and fleeing of innocent civilians in Kosovo.

In January 2000, President George W. Bush became President of the United States. His Secretary of State, Colin Powell, worked hard for the transfer of Slobodan Milosevic from a Belgrade prison to the ICTY. ${ }^{93}$ Powell pledged $\$ 181$ million to be committed at a donors' conference

88. C. Res. 827, Preamble, U.N. Doc. S/RES/827 (May 25, 1993).

89. Jerome Socolovsky, White House Blasts Kosovo Inquiry, ASSOCIATED PRESS ONLINE, JAN. 4, 2000 available at LEXISNEXIS.

90. John hagan, Justice in the Balkans: Prosecuting War Criminals in the Hague 208 (University of Chicago Press 2003).

91. Press Release, Justice Louise Arbour, Prosecutor ICTY, The Hague, J/PIU/404-E (May 27, 1999) available at http://www.icty.org/sid/7764 (last visited Sept. 9, 2009).

92. See Prosecutor v. Milosevic, Case No. IT-99-37, Indictment, available at http://www.icty.org/x/cases/slobodan_milosevic/ind/en/mil-ii990524e.htm (last visited Sept. 9, 2009).

93. JOHN HAGAN, supra note 90, at 207-12. 
created to assist the former Yugoslavia economy and confirmation that Milosevic would be transferred to ICTY. ${ }^{94}$ If not, the Bush administration made clear it would not participate in the donors' conference. ${ }^{95}$ Slobodan Milosevic arrived at the ICTY on 28 June $2001 .^{96}$ No United States nationals were indicted by the ICTY.

\section{THE UNITED STATES AND THE ICC}

On 15 June 1998, the Diplomatic Conference of Plenipotentiaries on the Establishment of an ICC commenced in Rome, Italy. ${ }^{97}$ At least 160 state delegations and international and nongovernmental organizations were present at the conference. ${ }^{98}$ The conference ended on 17 July 1998, with a vote for the adoption of a treaty for the ICC requested by the United States. ${ }^{99}$ As a result, 120 states voted in favor of the treaty, twenty-one abstained, and seven voted against the treaty. ${ }^{100}$ The Rome Statute of the ICC had been adopted and the majority of states were ready to make the ICC reality once sixty states ratified the statute. ${ }^{101}$ The United States, however, was one of seven states that had voted against the treaty. ${ }^{102}$

On 31 December 2000, President Clinton signed the Rome Statute, which was one of the final decisions made by the administration prior to leaving the White House. He signed so the United States could remain in subsequent negotiations concerning the ICC. However, soon after the Rome Statute received its sixtieth ratification, on 6 May 2002 the Bush Administration sent a letter addressed to UN Secretary General, Kofi

94. Id. at 208.

95. Id. at 210 .

96. For the prosecution of Slobodan Milosevic, see CHRIS STEPHEN, JUDGMENT DAY: THE Trial of Slobodan Milosevic (2005); Kingsley Chiedu Moghalu, Global Justice: THe Politics of War Crimes trials Ch. 3 (2008); Michael P. Scharf \& William A. Schabas, SLOBODAN MILOSEVIC ON TRIAL: A COMPANION (2002).

97. Colonel Stuart W. Risch, Hostile Outsider or Influential Insider? The United States and the International Criminal Court, 2009 ARMY LAW. 61, 67 at n.26 (2009).

98. Id. at 69 .

99. Rosaria Vigorito, The Evolution and Establishment of the International Criminal Court (ICC), 30 INT'L J. LEGAL INFO. 92, 93 (2002).

100. Id.
101. Id.
102. Id. 
Annan, formally renouncing any involvement in a treaty setting up the ICC by withdrawing the signature of the United States from the Rome Statute. ${ }^{103}$

After the "unsigning" of its signature to the Rome Statute, the United States vigorously tried to prevent the ICC from becoming a legitimate judicial system. On 2 August 2002, the United States passed the American Service Members' Protection Act, which would allow the United States to use military force against the ICC to free a citizen of the United States. ${ }^{104}$ It also forced many states that received financial and military support from the United States to sign bilateral immunity agreements under Article 98 of the Rome Statute. This was an attempt to ensure that state parties to the Rome Statute would not transfer an indicted citizen of the United States to the ICC.

There are several issues the United States has with the ICC. ${ }^{105}$ However, the issue of concern in this study is that the United States, by ratifying the Rome Statute, would be willing to allow the possibility of investigations and indictments against its military or civilian officials. It is not. In 1993, the United States supported the initiative to create the ICC ${ }^{106}$ with the view that it would be under the control of the SC similar to the ICTY and ICTR, which were created around the same time. In 1998 at the Rome Conference, the United States delegates pressed for the $\mathrm{SC}$ to have a role of overseeing possible "overzealous" prosecutors to prevent possible

103. Jonathon Wright, U.S. Renounces Obligations to International Court, REUTERS, May 6, 2002, pg. II, available at http:/www.geocities.com/honestabepolitics/bushPresWorldCourt2002.html (last visited Sept. 9, 2009).

104. William A. Schabas, An Introduction to the INTERnational Criminal Court 29-30 (Cambridge University Press 3d ed., 2007).

105. See alton frye, Toward an InTERnational Criminal Court? A Council Policy INITIATIVE (Alton Frye ed., Council on Foreign Relations, Inc. 1999); Dominic McGoldrick, Political Opposition to the ICC-The United States in DOMINIC MCGOLDRICK, PETER ROWE, AND ERIC Donnelly (eds.), The Permanent INTERnational CRIMINal COURT: Legal and Policy Issues 400, 401 (Hart Publishing 2004); JASON RALPH, DEFENDING THE SOCIETY OF STATES: Why AMERICA OPPOSES THE INTERNATIONAL CRIMINAL COURT AND IT VISION OF WORLD SOCIETY (Oxford University Press 2007); Monroe Leigh, The United States and the Statute of Rome, 95 AM. J. INT'L L. 124, 124 (2001); Sarah B. Sewall \& Carl Kaysen (eds.), The United States and the INTERnational CRIMINAL COURT: NATIONAL SECURITY AND INTERNATIONAL LAW (Rowman and Littlefield, Inc. 2000); William DRISCOll, Joseph ZOMPETTI, AND SuzeTte W. ZOMPETTI (eds.), THE International Criminal Court: Global POlitics and the Quest for Justice (International Debate Education Association 2004); see also Marc Grossman, Under Sec'y for Political Affairs, U.S. Dept. of State, Remarks to the Center for Strategic and International Studies, American Foreign Policy and the International Criminal Court (May 6, 2002); Jennifer K. Elsea, U.S. Policy Regarding the International Criminal Court, Report for Congress, updated Aug. 29, 2006 Congressional Research Service, Library of Congress.

106. See S. J. Res. 32, 103rd Cong. (1993); S. J. Res. 93, 103rd Cong. (1993). 
politicized prosecutions against United States nationals. ${ }^{107}$ The United States lost this debate and subsequently lost the vote to prevent the adoption of the Rome Statute.

The Rome Conference can mistakenly be viewed as a success for the United States, since it was David Scheffer ${ }^{108}$ who had pressed for the principle of complementarity, which was adopted, and Lieutenant Colonel William Lietzau ${ }^{109}$ who pressed for the inclusion of Elements of Crimes, which was also adopted and finalized at a later date. Yet, the United States lost at Rome. The United States did not want an ICC that could possibly indict a United States national. If the United States had gotten what it wanted and the ICC was controlled by the SC preventing possible indictments against the United States nationals through political muscle, other issues and concerns the United States has regarding the ICC would not be as relevant. ${ }^{110}$

Crimes against humanity and questionably genocide have occurred in Darfur in the past few years. The United States wanted an international criminal tribunal for Darfur as the mechanism for accountability. ${ }^{11}$ Without sufficient support on United States' proposals, the SC voted to refer the situation in Darfur to the ICC, which it is authorized to do under Article 13. ${ }^{112}$ Rather than use its veto power, the United States abstained allowing the resolution to pass, yet, only after proper safeguards were inserted protecting non-party states to the ICC. ${ }^{113}$

The abstention is not to be considered a warming to the ICC by the United States. ${ }^{114}$ The United States had always preferred the SC referring situations to the ICC. If this were how the ICC triggered cases, the United States would have ratified since most of their arguments have been

107. See Elsea, supra note 105 , at 6 .

108. David Scheffer, Ambassador at Large for War Crimes Issues, U.S. Dept. of State, Address Before the Comm. of Conscience, Responding to Genocide and Crimes Against Humanity (April 22, 1998).

109. William K. Lietzau, International Criminal Law After Rome: Concerns from a U.S. Military Perspective, 64 LAW \& CONTEMP. PROBS. 119, 121 (2001).

110. See generally William A. Schabas, United States Hostility to the International Criminal Court: It's All About the Security Council 15 E.J.I.L. 701, 701-720 (2004) (concerning the relationship between the SC and ICC regarding the United States' policy).

111. See Elsea, supra note 105 , at 22.

112. United Nations Diplomatic Conference of Plenipotentiaries on the Establishment of an International Criminal Court (July 17, 1998) 1 1, 3 art. 13(b), A/CONF. 183/9.

113. C. Res. 1593, ๆ 6, U.N. Doc. S/RES/1593 (2005).

114. But see Jess Bravin, U.S. Warms to Hague Tribunal, WALL ST. J. June 14, 2006, at A4. 
dependent on SC and ICC relations. ${ }^{115}$ However, since 2006 the United States has lessened its tone against the ICC and has acknowledged that it is willing to work with the court on a case-by-case basis when the ICC and the United States share a common interest, for example the situation in Darfur. ${ }^{16}$

\section{CONCLUSION}

It is yet to be determined if the United States policy on international criminal tribunals will change in the near future. It has been embedded in the United States culture that exceptions should be made for its military or political misconduct that result in war crimes, and if prosecutions occur, they occur within national courts, including military court martial. If the United States is to become a state party to the ICC, this culture will have to change. It is "implausible to seek total US immunity from investigation and prosecution for atrocity crimes as a state party to the Rome Statute." 117

It is also implausible that a United States national will not find $\mathrm{him} / \mathrm{herself}$ indicted by the ICC if the United States ratifies the Rome Statute. The United States has a very functional legal system, particularly its military justice system. It also has a history of prosecuting war crimes committed by its military service members. However, this history is not in good-standing international criminal law and its continuation would not meet the standards of the ICC. When the United States prosecutes military personal for crimes within the jurisdiction of the ICC, the defendants are not persons of higher authority. They usually consist of persons of subordinate authority. The goal of the ICC is to prosecute the very persons that the United States has been unwilling to prosecute regarding its own nationals. This unwillingness has been shown through its consistent history of participating in international criminal tribunals only when there is no substantial risk of United States nationals being indicted.

115. See generally William A. Schabas, supra note 104, at 701-20.

116. See Alexis Arieff, "Intemational Criminal Court Cases in Africa: Status and Policy Issues" Congressional Research Service Report for Congress, 12 September 2008, (CRS RL34665, Library of Congress); see also Press Release, Security Council, Security Council Declares Intention to Cnsider Sanctions to Obtain Sudan's Full Compliance with Security, Disarment Obligations on Darfur, U.N. Doc. SC/8191 (Sept. 18, 2004).

117. David SChEFFer \& John Hutson, StRategy for U.S. ENGagement WITH THE INTERNATIONAL CRIMINAL COURT 10 (2008). 